\begin{tabular}{|c|c|c|c|c|}
\hline \multicolumn{5}{|c|}{$\begin{array}{l}\text { Table. Mean change from baseline (SD) in total modified vdH-S score stratified by CDAl, DAPSA, } \\
\text { PASDAS, MDA, and VLDA in PSA patients from GO-VIBRANT }\end{array}$} \\
\hline & \multicolumn{2}{|c|}{ Baseline to Wk24 } & \multicolumn{2}{|c|}{ Baseline to Wk52 } \\
\hline & PBO & GLM $2 \mathrm{mg} / \mathrm{kg}$ & $\mathrm{PBO} \rightarrow \mathrm{GLLM} 2^{2}$ & GLM $2 \mathrm{mg} / \mathrm{kg}$ \\
\hline \multicolumn{5}{|l|}{ DAPSA } \\
\hline $\begin{array}{l}\text { Remission-fow disease activity }(\leq 14), n \\
\text { Mean change (SD) }\end{array}$ & $\begin{array}{c}10 \\
-0.05 \pm 2.14\end{array}$ & $\begin{array}{c}107 \\
-0.64 \pm 1.66\end{array}$ & $\begin{array}{c}105 \\
1.49 \pm 4.96\end{array}$ & $\begin{array}{c}119 \\
-0.88 \pm 2.34\end{array}$ \\
\hline p-value & & 0.4422 & & $<0.001$ \\
\hline Moderate disease activity $(>14-28), n$ & 37 & & 66 & \\
\hline $\begin{array}{l}\text { Mean change (SD) } \\
\text { p-value }\end{array}$ & $0.29 \pm 1.81$ & $\begin{array}{c}-0.32+1.54 \\
0.0268\end{array}$ & $1.38 \pm 4.16$ & $\begin{array}{l}-0.48 \pm 1.82 \\
0.0025\end{array}$ \\
\hline Active disease activity $(>28), n$ & 190 & 71 & 66 & 54 \\
\hline $\begin{array}{l}\text { Mean change (SD) } \\
\text { p-value }\end{array}$ & $1.77 \pm 3.56$ & $0.21+1.97$ & $1.27 \pm 4.36$ & $0.41+3.30$ \\
\hline \multicolumn{5}{|l|}{ PASDAS } \\
\hline Inactive disease activity $(\leq 3.2), \mathrm{n}$ & 12 & 101 & 114 & 118 \\
\hline $\begin{array}{l}\text { Mean change (SD) } \\
\text { p-value }\end{array}$ & $-0.17 \pm 2.136$ & $\begin{array}{l}-0.64+1.729 \\
0.4305\end{array}$ & $1.53 \pm 4.850$ & $-1.01+2.384$ \\
\hline $\begin{array}{l}\text { poderate disease activity }(>3.2 \&<5.4), n \\
\text { node de }\end{array}$ & 85 & $\begin{array}{l}.4309 \\
109\end{array}$ & 83 & \\
\hline $\begin{array}{l}\text { Mean change (SD) } \\
\text { p-value }\end{array}$ & $0.73 \pm 1.926$ & $\begin{array}{c}-0.16 \pm 1.750 \\
0.0003\end{array}$ & $1.14 \pm 3.727$ & $\begin{array}{l}-0.20 \pm 1.965 \\
0.0055\end{array}$ \\
\hline High disease activity (25.4), n & 125 & 22 & 19 & \\
\hline $\begin{array}{l}\text { Mean change (SD) } \\
\text { p-value }\end{array}$ & $2.29 \pm 4.107$ & $\begin{array}{l}0.47 \pm 1.891 \\
0.0290\end{array}$ & $3.81 \pm 7.052$ & $\begin{array}{c}0.54 \pm 3.066 \\
0.1122\end{array}$ \\
\hline \multicolumn{5}{|l|}{ MDA } \\
\hline Yes, $\mathrm{n}$ & 11 & 78 & 80 & 101 \\
\hline $\begin{array}{l}\text { Mean change (SD) } \\
\text { p-value }\end{array}$ & $0.91+2.49$ & $\begin{array}{c}-0.83+1.78 \\
0.0232\end{array}$ & $1.19 \pm 3.86$ & $\begin{array}{l}-1.16+2.46 \\
<0.0001\end{array}$ \\
\hline No, $n$ & 226 & 159 & 157 & 136 \\
\hline Mean change (SD) & $1.49 \pm 3.39$ & $-0.05 \pm 1.70$ & $1.50 \pm 4.90$ & $0.03 \pm 2.44$ \\
\hline \multicolumn{5}{|l|}{ VLDA } \\
\hline Yes, n & 1 & 16 & 24 & 35 \\
\hline $\begin{array}{l}\text { Mean change (SD) } \\
\text { p-value }\end{array}$ & 0 & $\begin{array}{c}-0.91+1.04 \\
0.3749\end{array}$ & $0.91+3.32$ & $\begin{array}{c}-1.49+2.22 \\
0.0041\end{array}$ \\
\hline No, $n$ & 236 & 221 & 213 & 202 \\
\hline $\begin{array}{l}\text { Mean change (SD) } \\
\text { p-value }\end{array}$ & $1.47 \pm 3.36$ & $-0.26+1.80$ & $1.45 \pm 4.69$ & $-0.30+2.52$ \\
\hline \multirow{2}{*}{\multicolumn{5}{|c|}{ CDAl }} \\
\hline & & & & \\
\hline Remission $(\leq 2.8), n$ & 5 & 43 & 58 & 63 \\
\hline $\begin{array}{l}\text { Mean change (SD) } \\
\text { p-value }{ }^{b}\end{array}$ & $-0.60 \pm 1.34$ & $\begin{array}{l}-0.80 \pm 1.76 \\
0.9170\end{array}$ & $1.52 \pm 5.55$ & $\begin{array}{c}-1.06 \pm 2.41 \\
0.0003\end{array}$ \\
\hline Low disease activity $(>2.8 \& \leq 10), n$ & 28 & 98 & 78 & 92 \\
\hline $\begin{array}{l}\text { Mean change (SD) } \\
\text { p-value }\end{array}$ & $0.77 \pm 2.01$ & $\begin{array}{l}-0.41+1.43 \\
0.0011\end{array}$ & $1.21+3.59$ & $\begin{array}{l}-0.81+2.12 \\
<0.0001\end{array}$ \\
\hline $\begin{array}{c}\text { p-value } \\
\text { Moderate disease activity }(>10 \& \leq 22), n\end{array}$ & 67 & $\begin{array}{c}0.011 \\
66\end{array}$ & 64 & 69 \\
\hline $\begin{array}{l}\text { Mean change (SD) } \\
\text { p-value }\end{array}$ & $0.88 \pm 2.73$ & $\begin{array}{l}-0.10 \pm 2.04 \\
0.0429\end{array}$ & $1.32+4.25$ & $\begin{array}{c}0.20 \pm 2.82 \\
0.0905\end{array}$ \\
\hline High disease activity (>22), n & 137 & 30 & 37 & 13 \\
\hline $\begin{array}{l}\text { Mean change (SD) } \\
\text { p-value }\end{array}$ & $1.96 \pm 3.79$ & $\begin{array}{c}0.30 \pm 1.95 \\
0.0079\end{array}$ & $1.75 \pm 5.34$ & $\begin{array}{c}1.11+2.65 \\
0.8144\end{array}$ \\
\hline \multicolumn{5}{|c|}{$\begin{array}{l}\text { CDAl=Clinical Disease Activity Index; DAPSA=Disease Activity in Psoriatic Arthritis score; } G L M=\text { golimumab; } \\
\text { MDA=Minimal Disease Activity; PBO=placebo; PASDAS=Psoriatic Arthritis Activity Score; } P \text { PA=active psoriatic } \\
\text { arthritis; SD=standard deviation; vdH-S=van der Heijde-Sharp; VLDA=Very Low Disease Activity } \\
\text { aPBO pts crossed over to IV GLM } 2 \mathrm{mg} / \mathrm{kg} \text { at Wk24. } \\
\text { bP-value is based on ANOVA w/Van der Waerden rank test }\end{array}$} \\
\hline
\end{tabular}

Inc., Janssen, Lilly, Novartis, Pfizer, SUN and UCB, Speakers bureau: AbbVie, Amgen, BMS, Celgene, Genentech, Janssen, Lilly, Novartis, Pfizer and UCB, M Elaine Husni Grant/research support from: Janssen, Shelly Kafka Shareholder of: J\&J, Employee of: J\&J, Soumya D Chakravarty Shareholder of: Johnson \& Johnson, Employee of: Johnson \& Johnson, Diane D Harrison Employee of: Janssen Research \& Development, LLC, Kim Hung Lo Employee of: Janssen Research \& Development, LLC, Stephen Xu Employee of: Employee of Janssen Research \& Development, LLC, Elizabeth C Hsia Employee of: Employee of Janssen Research \& Development, LLC, Arthur Kavanaugh Grant/research support from: UCB Pharma

DOI: 10.1136/annrheumdis-2019-eular.180

\section{SAT0390 GUSELKUMAB WAS MORE EFFECTIVE THAN SECUKINUMAB IN PATIENTS WITH PLAQUE PSORIASIS AND THE SUBSET OF PATIENTS WITH SELF- REPORTED PSORIATIC ARTHRITIS IN THE RANDOMIZED, DOUBLE-BLIND, HEAD-TO-HEAD COMPARISON STUDY ECLIPSE OVER 1 YEAR}

Joseph F. Merola ${ }^{1}$, LI Shu' ${ }^{2}$, Ming-Chun Hsu², Chetan Karyekar ${ }^{3}$, Susan Flavin ${ }^{2}$ Bruce Randazzo ${ }^{2}$, Laura C. Coates ${ }^{4} .{ }^{1}$ Brigham and Women's Hospital, Harvard Med School, Boston, United States of America; ${ }^{2} J a n s s e n$ Research and Development, LLC, Spring House, United States of America; ${ }^{3}$ Janssen Medical Affairs, Horsham, United States of America; ${ }^{4}$ Oxford University, Oxford, United Kingdom

Background: Guselkumab (GUS, an antibody against IL-23) and secukinumab (SEC, an antibody against IL-17A) are both approved for the treatment of psoriasis (PsO). Up to $30 \%$ of patients with $\mathrm{PsO}$ may have psoriatic arthritis (PsA).

Objectives: The ECLIPSE study compared efficacy and safety of GUS vs SEC in patients with plaque PsO. Post hoc analyses examined outcomes in the subgroup of patients with self-reported psoriatic arthritis (PsA).

Methods: ECLIPSE was a randomized, double-blind trial of adults with moderate-to-severe plaque PsO who received GUS $100 \mathrm{mg}$ at Weeks 0 , 4, then every 8 weeks, or SEC $300 \mathrm{mg}$ at Weeks $0,1,2,3$, and 4 , then every 4 weeks, both through Week 44 . The primary endpoint was the proportion of patients achieving $\geq 90 \%$ improvement compared to baseline in the Psoriasis Area and Severity Index (PASI) score at Week 48. Cochran-Mantel Haenszel chi-square testing stratified by investigator was used to compare treatment-group responses.

Results: Overall, treatment groups [GUS $(n=534)$, SEC $(n=514)$ ] were comparable at baseline: weight $89 \mathrm{~kg}, 24 \%$ body surface area $\mathrm{PsO}$, and Investigator Global Assessment (IGA) moderate (76\%) or severe (24\%). These characteristics were similar to those of subgroups with self-reported PsA [GUS ( $n=97)$, SEC $(n=79)]$. In the overall population, the primary endpoint of PASI 90 response at Week 48 was achieved by $84.5 \%$ of GUS vs $70.0 \%$ of SEC patients (treatment difference $14.2[95 \%$ $\mathrm{Cl}=9.6 \%, 18.8 \%], \mathrm{P}<0.001)$. Among patients with $\mathrm{PsA}$, the primary endpoint of PASI 90 response at Week 48 was achieved by $82.5 \%$ of GUS vs 63.3\% of SEC patients (treatment difference 19.2\% [95\% Cl=5.0\%, $33.4 \%]$ ). Beyond week 20, in both the overall study population and the PsA subpopulation, GUS-treated patients maintained the PASI 90 response while SEC-treated patients had a reduction in response through week 48 (Figure). In the overall population, results of the first major secondary endpoint (proportion of patients with a PASI 75 response at both Week 12 and 48 ) showed non-inferiority of GUS vs SEC (GUS-84.6\% vs SEC- $80.2 \%$ of patients, $\mathrm{p}<0.001)$, but superiority was not demonstrated $(\mathrm{p}=0.062)$. Adverse events observed in the overall population and PsA subgroup were generally consistent with the established safety profiles for GUS and SEC.

Conclusion: In the subset of patients with self-reported PsA in the ECLIPSE study, GUS demonstrated better maintenance of response and higher efficacy at approximately one year compared with SEC in the treatment of moderate to severe plaque PsO. These findings were consistent with those for the overall study population of patients with plaque PsO. AEs observed were generally consistent with the established safety profiles for GUS and SEC.

Disclosure of Interests: Joseph F Merola Grant/research support from: Janssen, Shu Li Employee of: Janssen Research \& Development, LLC, Ming-Chun Hsu Employee of: Janssen Research \& Development, LLC, Chetan Karyekar Shareholder of: J\&J, Employee of: Janssen Scientific

Figure. Proportion of Patients Achieving PASI 90 Response $(95 \% \mathrm{Cl})$

A.

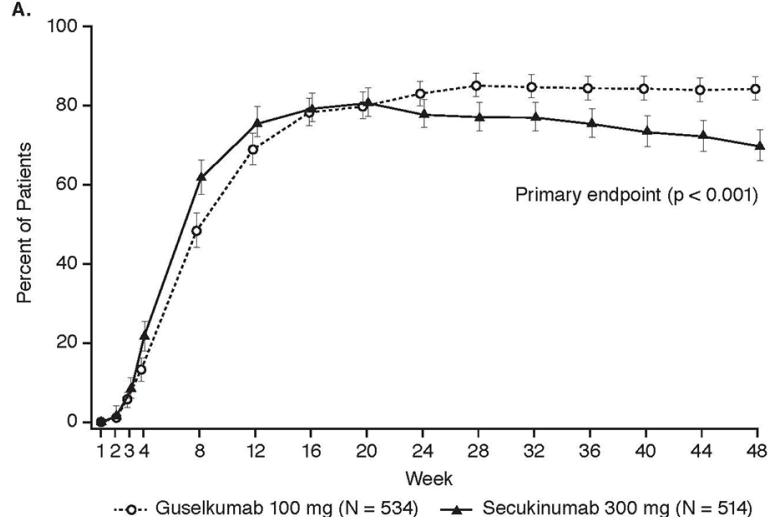

B.

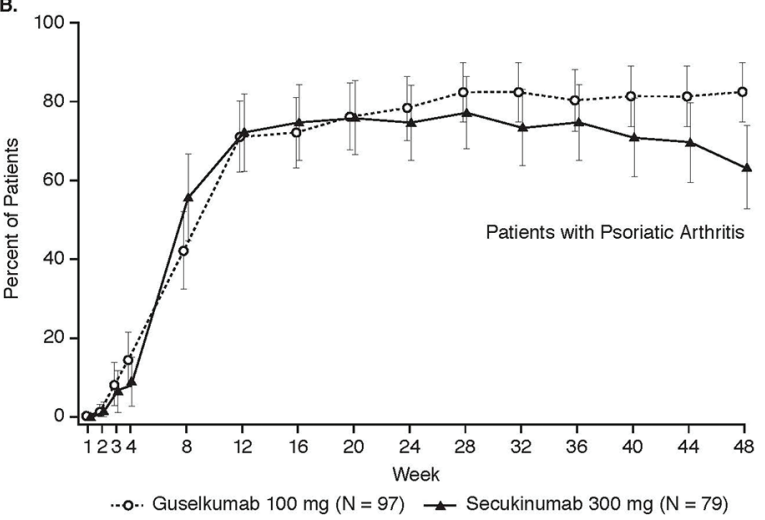

A. Total ECLIPSE population of patients with moderate to severe plaque psoriasis. B. Subgroup of patients with Psoriatic Arthritis.

Non-responder imputation was used for missing data.

$\mathrm{Cl}=$ Confidence interval, PASI $90=90 \%$ improvement in the Psoriasis Area and Severity Index (PASI). 
Affairs, LLC, Abbott, BMS, Novartis, Susan Flavin Employee of: Janssen Research \& Development, LLC, Bruce Randazzo Employee of: Janssen Research \& Development, LLC, Laura C Coates Grant/research support from: AbbVie, Celgene, Lilly, Novartis and Pfizer, Consultant for: AbbVie, Amgen, BMS, Celgene, Galapagos, Gilead Sciences Inc., Janssen, Lilly, Novartis, Pfizer, Prothena Corp and UCB DOI: 10.1136/annrheumdis-2019-eular.1980

\section{SAT0391 REMISSION AND DRUG RETENTION RATES OF SECUKINUMAB IN 1549 PATIENTS WITH PSORIATIC ARTHRITIS TREATED IN ROUTINE CARE - POOLED DATA FROM THE OBSERVATIONAL EUROSPA RESEARCH COLLABORATION NETWORK}

Brigitte Michelsen, Cecilie Heegaard Brahe, Lennart T.H. Jacobsson, Michael Nissen, Manuel Pombo-Suarez, Heřman Mann, Ziga Rotar, Joe Sexton, Maria Jose Santos, Dan Nordström, Catalin Codreanu, Björn Gudbjornsson, Sema Yilmaz, Florenzo lannone, Ulf Lindström, Anne Gitte Loft, Burkhard Moeller, Carlos Sánchez-Piedra, Karel Pavelka, Matija Tomsic, Eirik Kristianslund, Helena Santos, Anna-Mari Hokkanen, Ruxandra lonescu, Thorvardur Jon Love, Yavuz Pehlivan, Marco Sebastiani, Gareth T. Jones, Irene van der Horst-Bruinsma, Lise Hyldstrup, Niels Steen Krogh, Merete L. Hetland, Mikkel stergaard. EurSA Research Collaboration, on behalf of DANBIO (Denmark), ARTIS (Sweden), SCQM (Switzerland), NOR-DMARD (Norway), ATTRA (Czech Republic), Reuma pt (Portugal), BIOBADASER (Spain), ROB-FIN (Finland), biorx.si (Slovenia), ICEBIO (Iceland), TURKBIO (Turkey), RRBR (Romania), ARC (Netherlands), BSRBR-AS (UK), GISEA (Italy), Denmark

Background: There is a lack of data on exposure, treatment outcomes and retention rates of secukinumab in patients with psoriatic arthritis (PsA) treated in routine care.

Objectives: Primary objective: To assess the proportion of PsA patients in remission after 6 months of secukinumab treatment across Europe. Secondary objectives: To compare baseline clinical and demographic characteristics, 6-month crude and LUNDEX adjusted remission rates, 6month retention rates and median time to secukinumab withdrawal (due to loss of efficacy/adverse events) between bDMARD naïve and nonnaïve patients as well as across the participating European registries. Methods: PsA patients starting secukinumab in routine care and followed for at least 6 months were included from 12 European registries within the European Spondyloarthritis Research Collaboration (EuroSpA). Independent t-test, Mann-Whitney $U$ test, ANOVA, Kruskal-Wallis and Chisquare test were used for group comparisons as appropriate, and Kaplan-Meier plots with log rank test for comparison of secukinumab drug survival.

Results: A total of 1549 PsA patients starting secukinumab were included (Table). 6-month remission and retention rates were significantly different between the registries (Table). Biologic DMARD (bDMARD) naïve compared with non-naïve patients had significantly higher 6-month remission rates and a trend towards better 6-month retention rates (Table, Figure $1 \mathrm{a}-\mathrm{b})$.

Conclusion: This study of $>1500$ patients in 12 European countries provides real-world data on the effectiveness of secukinumab in patients with PsA, adding evidence to existing RCTs. A majority of the patients had long disease duration and was previous bDMARD users. DAS28CRP, SDAI and DAPSA28 remission at 6 months were achieved by $35 \%, 12 \%$ and $12 \%$, respectively. The overall retention rate was $86 \%$, with significant differences across the registries. bDMARD naïve compared with nonnaïve patients had significantly better 6-month remission rates and a trend towards better secukinumab retention rates.

Acknowledgement: Novartis Pharma AG and IQVIA for supporting the EuroSpA collaboration

Disclosure of Interests: Brigitte Michelsen Grant/research support from: Unrestricted grant: Novartis, Consultant for: Novartis, UCB, Cecilie Heegaard Brahe Grant/research support from: Unrestricted grant: Novartis, Lennart T.H. Jacobsson Consultant for: LJ has received lecture and consulting fees from Pfizer, Abbvie, Novartis, Eli-Lily and Janssen, Michael Nissen Consultant for: AbbVie, Lilly, Novartis, and Pfizer, Manuel Pombo-Suarez: None declared, Heřman Mann Consultant for: Pfizer, Eli Lilly, Sanofi, Speakers bureau: AbbVie, Roche, Pfizer, MSD, Eli Lilly, Sanofi, Ziga Rotar: None declared, Joe Sexton: None declared, Maria Jose Santos: None declared, Dan Nordström Grant/research support from: MSD, Pfizer, Consultant for: AbbVie, BMS, MSD, Novartis, Roche, Pfizer, UCB, Speakers bureau: Novartis, UCB, Catalin Codreanu: None
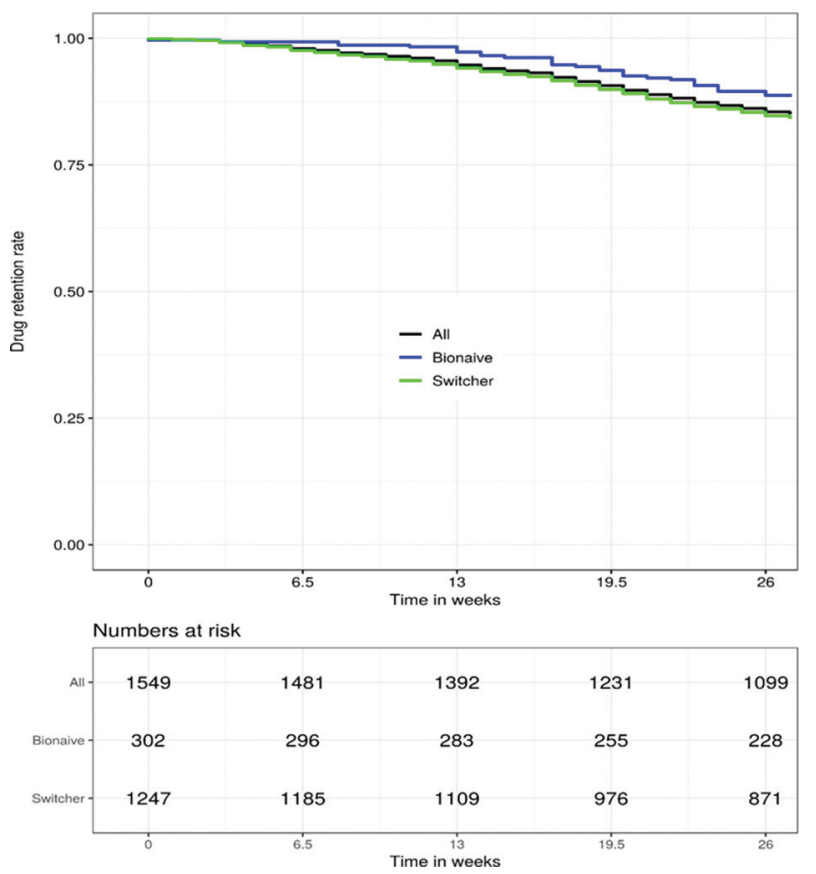

Figure 1. a Overall 6-month secukinumab retention rate in EuroSpA as well as compared between bDMARD naïve and non-naïve patients (Kaplan-Meier, log rank test; $p=0.07$ )

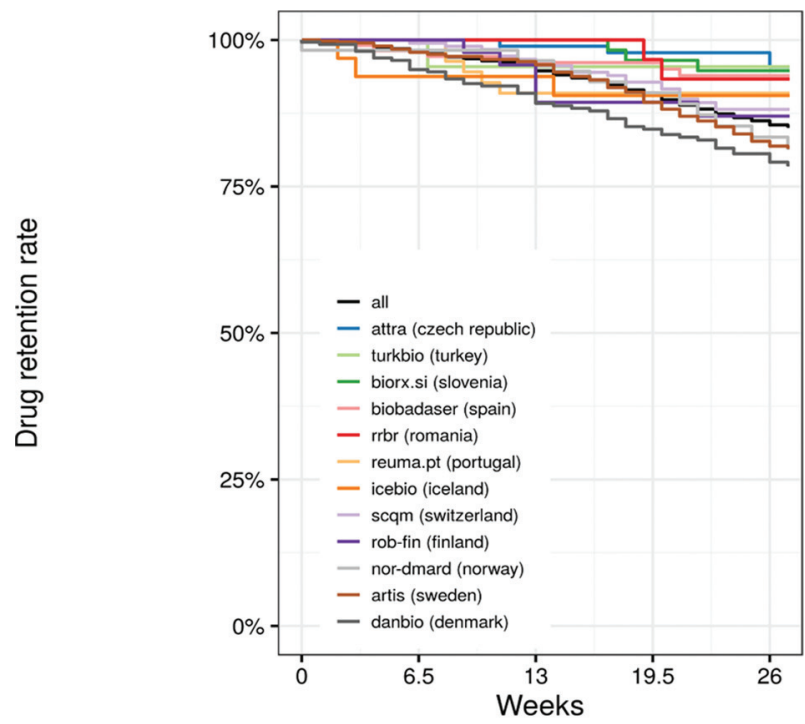

Numbers at risk

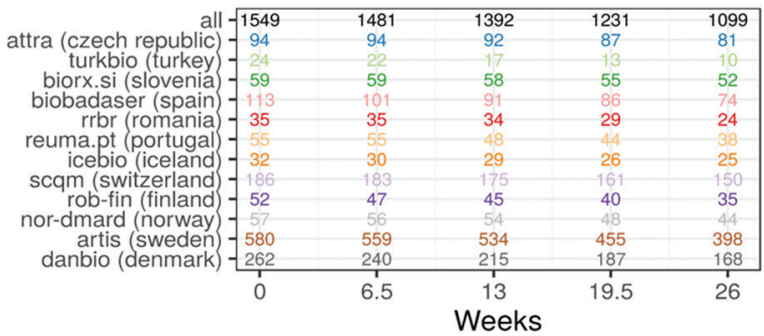

Figure 1. b 6-month secukinumab retention rates overall and compared across the different registries in the EuroSpA collaboration (Kaplan-Meier, log rank test; $p<0.001$ ) 


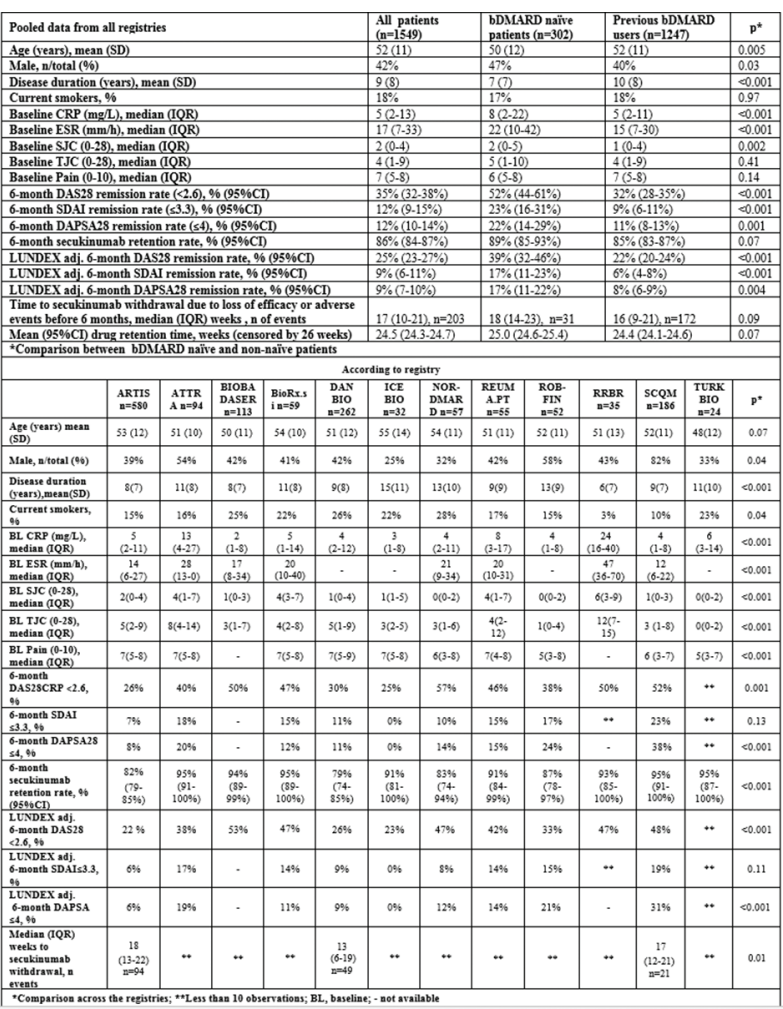

declared, Björn Gudbjornsson: None declared, Sema Yilmaz: None declared. Florenzo lannone Consultant for: $F$ lannone has received consultancy fees and/or speaker honoraria from Pfizer, AbbVie, MSD, BMS, Novartis, Lilly, UCB outside this work, Speakers bureau: F lannone has received consultancy fees and/or speaker honoraria from Pfizer, AbbVie, MSD, BMS, Novartis, Lilly, UCB outside this work, Ulf Lindström: None declared, Anne Gitte Loft: None declared, Burkhard Moeller Consultant for: Swissmedic Human Medicines Expert Committee Member (regulatory agency), Carlos Sánchez-Piedra: None declared, Karel Pavelka: None declared, Matija Tomsic: None declared, Eirik kristianslund: None declared, Helena Santos: None declared, Anna-Mari Hokkanen: None declared, Ruxandra lonescu: None declared, Thorvardur Jon Love Consultant for: Received reimbursment from Celgene for speaking about guidelines for the treatment of psoriatic arthritis, Yavuz Pehlivan: None declared, Marco Sebastiani: None declared, Gareth T. Jones Grant/ research support from: Have received research grants (not current) from Abbvie and Pfizer.

Have received research grants (not current) from the British Society for Rheumatology, who received the funds from Abbive, Pfizer and UCB. Have received research grant (current) from the British Society for Rheumatology, who received the funds from Celgene., Irene van der HorstBruinsma Grant/research support from: MSD, Pfizer, AbbVie, Consultant for: Abbvie, UCB, MSD, Novartis, Speakers bureau: BMS, AbbVie, Pfizer, MSD, Lise Hyldstrup: None declared, Niels Steen Krogh: None declared, Merete L. Hetland Grant/research support from: BMS, MSD, AbbVie, Roche, Novartis, Biogen, Pfizer, Consultant for: Eli Lilly, Speakers bureau: Orion Pharma, Biogen, Pfizer, CellTrion, Merck, Samsung Bioepis, Mikkel stergaard Grant/research support from: Abbvie, Celgene, Centocor, Merck, Novartis, Consultant for: Abbvie, BMS, Boehringer-Ingelheim, Celgene, Eli Lilly, Hospira, Janssen, Merck, Novartis, Novo, Orion, Pfizer, Regeneron, Roche, and UCB, Speakers bureau: Abbvie, BMS, Boehringer-Ingelheim, Celgene, Eli Lilly, Hospira, Janssen, Merck, Novartis, Novo, Orion, Pfizer, Regeneron, Roche, and UCB

DOI: 10.1136/annrheumdis-2019-eular.2233

\section{SAT0392 IMPLEMENTING THE PSORIATIC ARTHRITIS DISEASE ACTIVITY SCORE (PASDAS) IN ROUTINE CLINICAL PRACTICE: (IM)POSSIBLE?}

Michelle Mulder ${ }^{1}$, Alfons den Broeder ${ }^{1,2}$, Berbke van Ginneken ${ }^{1}$, Johanna Vriezekolk ${ }^{1}$, Elien Mahler ${ }^{1}$, Frank van den Hoogen ${ }^{1,2}$, Mark Wenink ${ }^{1}$. ${ }^{1}$ Sint Maartenskliniek, Rheumatology, Ubbergen, Netherlands; ${ }^{2}$ Radboud University Medical Center, Rheumatic Diseases, Nijmegen, Netherlands

Background: Psoriatic arthritis (PsA) is a heterogeneous disease, with involvement of at least five health domains: peripheral joint disease, enthesitis, dactylitis, axial involvement, and skin and nail psoriasis. Because of the heterogeneity of the disease, assessment of disease activity is challenging. One of the many single or composite outcome measures that has been developed is the Psoriatic Arthritis Disease Activity Score (PASDAS). The PASDAS is a comprehensive measure that takes arthritis (66/68 joint score), dactylitis, enthesitis, CRP, physician disease activity VAS score and patient-reported outcomes into account ${ }^{1}$. Furthermore, it is a continuous outcome measure in contrast to the Minimal Disease Activity criteria (MDA), facilitating the longitudinal follow-up of disease activity. The PASDAS also has better parametric distribution and discriminative capacity compared to other outcome measures such as the Disease Activity for PSoriatic Arthritis score (DAPSA). However, feasibility of PASDAS use in routine clinical care has been questioned due to its complexity. It requires a CRP and filled-out SF36 form at time of assessment, does not include a formal skin assessment, is difficult to calculate and is time consuming for both patient and physician.

Objectives: To implement PASDAS measurements and skin assessments in routine clinical care for all 1300 PsA patients treated at our centre. Methods: The implementation consisted of the following stages: 1) assessment of patients' acceptability of measurement burden; 2) implementation of mathematical calculations of the PASDAS in our electronic health record; 3) PASDAS and skin assessment training of rheumatology nurses and rheumatologists; and 4) (logistic) adjustments to the outpatient visit.

Results: Our patient partners preferred comprehensive clinical assessment of skin and joints above a limited assessment (such as the DAS28-CRP), although the latter would be less time consuming. For this reason, and to comply with international guidelines, we decided to also add assessment of skin disease, by using the Body Surface Area (BSA) and Physician Global Assessment score (PGA). Furthermore, research demonstrated that for the PASDAS calculation the physical component score (PCS) of the SF36 could be substituted by the SF12$\mathrm{PCS}^{2}$. As the SF12 is more concise, minimizing patient burden, we chose to implement the SF12 instead of the SF36. The SF12-PCS, together with the other separate component scores and corresponding mathematical calculation of the PASDAS, was implemented in our electronic health record. Lastly, we set-up a three phase consultation that consists of laboratory tests and consultation with a rheumatology nurse who performs the physical measurements before each visit with the physician.

Conclusion: Standardized and routine measurement of the PASDAS and skin involvement at each outpatient visit of all our PSA patients before consultation with the treating rheumatologist was successfully implemented, underscoring the feasibility of this approach. In addition to improving clinical care, routine outcome measurements can be used for a variety of clinical studies.

\section{REFERENCES}

[1] Helliwell, P.S., et al., The development of candidate composite disease activity and responder indices for psoriatic arthritis (GRACE Project). Ann of the Rheum Dis. 2013 Jun;72(6):986-91.

[2] Helliwell, P.S, et al., Modification of the Psoriatic Arthritis Disease Activity Score (PASDAS). Ann Rheum Dis. 2018 Mar;77(3):467-468.

Disclosure of Interests: Michelle Mulder: None declared, Alfons den Broeder: None declared, Berbke van Ginneken: None declared, Johanna Vriezekolk: None declared, Elien Mahler: None declared, Frank van den Hoogen: None declared, Mark Wenink Consultant for: abbvie DOI: 10.1136/annrheumdis-2019-eular.2758 